UDC 669. 14.018. 258. 8

\title{
新しい熱間ダイス鋼“MAX 1”について
}

伊藤一夫*, 磯 部 晋**, 加 藤 毅*

\section{A new Hot-Work Die Steel "MAX1"}

Kazuo Itô, Susumu Isobe and Tsuyoshi Katô

Synopsis

MAX $1(0.3 \mathrm{C}, 4 \mathrm{Cr}, 0.6 \mathrm{Mo}, 1 \mathrm{~W}, 0.4 \mathrm{~V}, 2 \mathrm{Co})$ is a new hot-work die steel alloy-designed to retain the least of undisolved carbides in quenched condition and to obtain secondary precipitations well enough.

This steel proves that it has excellent ductility together with high strength and that it satisfies various demands for heavy-duty hot-work dies as follows:

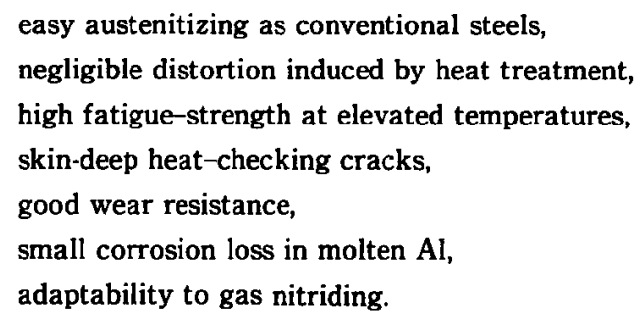

1.はじめに

熱間ダイスの使用条件は，設備の大型化および 自動化が進むにつれてきびしくなっており，これ らの要求に対処するため強勒なダイス鋼が数多く

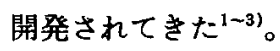

これらの鋼は，一般に炭化物の析出硬化によっ て強度を上げており，炭化物形成元素の添加量が 增加してきている。また，それにともなって焼入 れ時に末固溶のまま残る炭化物量も增加してきて いる。

この未固溶炭化物は強化に寄与しないばかり

昭和51年11月19日 受付

*大同特殊鋼研究開発本部中央研究所 浡川 研究室

**日本原子力研究所 留学中
か，介在物と同様の切欠作用により鋼の辇性を損 っている場合が多い。このよらな観点からマトリ ックス鋼として MAX 2 鋼が合金設計された。し かし，現用のダイス鋼より高い温度から焼入れて いるにもかかわらず，まだ末固溶炭化物の残留が あった。

そこでMAX 2 における炭化物举動の詳細な検 討結果をもとに合金の再設計を行い，未固溶炭化 物をさらに减少させた MAX 1 を開発した。この 合金は高強度と高勒性を兼備した熱間ダイス鋼で あることが確認されたので，以下にその諸特性を 紹介する。

\section{2. 供試材および実験方法}

本実験では MAX 1 を他のダイス鋼と比較検討 して，その特對を明確にすることとした。 Table 1 に供試材の化学成分を示す。比較材として用い 
Table 1. Chemical compositions.

wt (\%)

\begin{tabular}{c|c|c|c|c|c|c|c|c|c}
\hline \hline Specimen & $\mathrm{C}$ & $\mathrm{Si}$ & $\mathrm{Mn}$ & $\mathrm{Cr}$ & $\mathrm{Mo}$ & $\mathrm{W}$ & $\mathrm{V}$ & $\mathrm{Co}$ & Remark \\
\hline MAX1 & 0.33 & 0.29 & 0.29 & 3.92 & 0.59 & 0.91 & 0.41 & 2.02 & $\begin{array}{c}\text { mod. } \\
\text { MAX2 }\end{array}$ \\
\hline \hline MAX2 & 0.40 & 0.27 & 0.23 & 4.16 & 1.38 & 4.10 & 0.47 & 1.98 & $\begin{array}{c}\text { mod. } \\
\text { H19 }\end{array}$ \\
\hline \hline SKD61 & 0.38 & 0.89 & 0.40 & 4.96 & 1.23 & - & 0.93 & - & JIS SKD61 \\
\hline SKD62 & 0.38 & 0.93 & 0.35 & 5.17 & 1.40 & 1.48 & 0.43 & - & JIS SKD62 \\
\hline
\end{tabular}

た MAX 2 は, MAX 1 の母体となった合金であ る。また現用の熱間ダイス鋼としては SKD 61 お よびSKD 62 をとり上げた。いずれの材料も不純 物含有量は低い。

MAX 1 およびMAX 2 は 2 ton フーク炬で

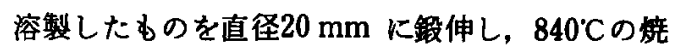
なましを施した。.SKD 61 および SKD 62 は工場 の製品から採取した棒材を直径 $20 \mathrm{~mm}$ に再鍛 し，860の既なましを施して実験に供した。

試験片形状および測定方法は多岐にわたるの で，実験結果をのべる際に随時説明する。

なお試験片の熱処理はすべて塩浴妒で行った。

\section{3. 実験結果と考寄}

\section{1 M A X 1 の熱処理}

(1) 熱処理かたさ

MAX 1 の熱処理特性を主としてかたさの变化 から検討した。

Fig. 1 に焼入九温度と諸特性の関係を示す。図 中(d)の焼入れままおよび(c)の㛙もどし後のかたさ の変化をみると，焼入れ温度の上昇にともなって，

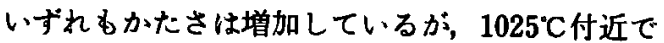
的和值に達している。この温度は(e)の電子顕徽鏡 視野上で測定した末固溶炭化物量（定量法につい ては育照)が最低値に近くなったところである。

これより高い温度から㒯入れると(a)に示したよ 5に粒成長が著しくなり，同時に(b)の衝撃値る低 下する。

以上の結果を総合すると，MAX 1 の最適㜔入 れ温度範囲は1000 1050である。SKD 61 おょ びSKD 62 と同じ焼入れ温度で処理できることが 判明した。

これに対して，比較材の MAX 2 について上の よらな検討を行った結果によれば，最墑雄入れ温

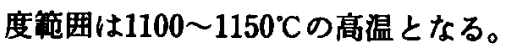

つぎに Fig. 2 で 3 鋼種の䇮もどしかたさを比 较した。MAX 1 の措入れままおよび低温焼もど し後のかたさは他の 2 鋼種に比較して低くなって いるが, $600^{\circ} \mathrm{C}$ 以上の嘅むどしでは SKD 62 よりす 高い値を示している。したがって熱間ダイスの使

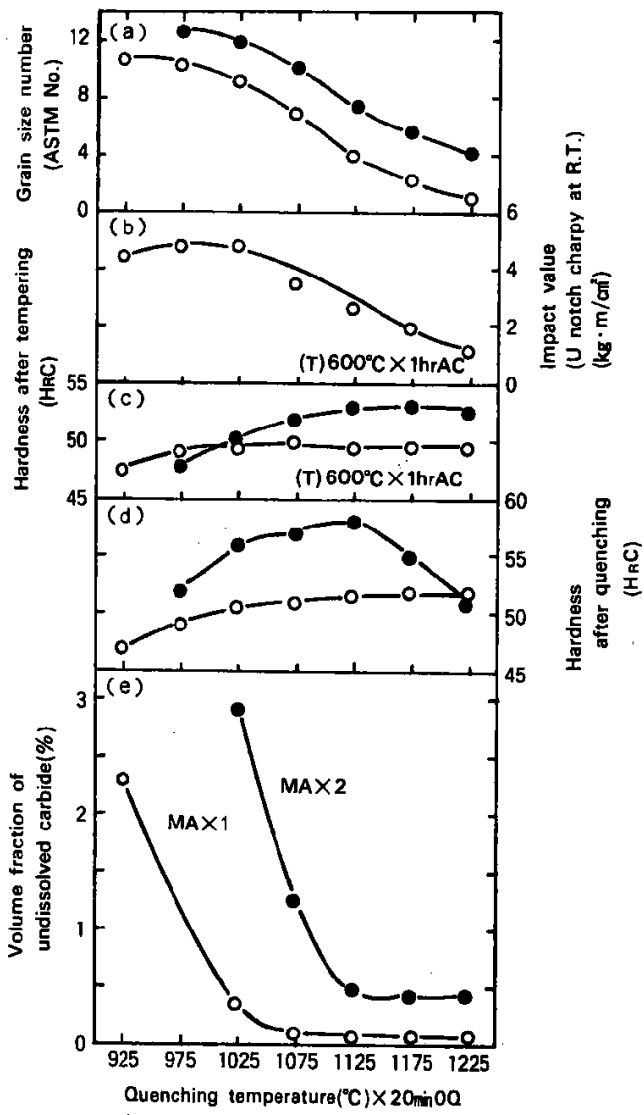

Fig. 1. Effect of quenching temperatures on various properties of MAX 1 and MAX 2. 


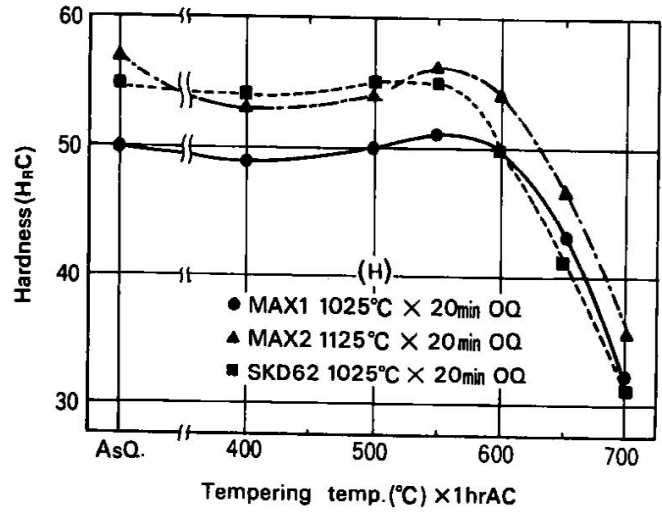

Fig. 2. Tempering curves for MAX 1, MAX 2 and SKD62.

用温度範囲では，十分な軟化抵抗性を持っている と考えられる。

（2）熱処理にともな5組織変化

MAX 1 の開発に当っては，焼入れ時の未固溶 炭化物を減少させることに重点をおいて合金設計 を行っているので，以下に本合金中の炭化物の挙 動について検討した。

まず, Photo. 1 にMAX 1 の光学顕徽鏡組織を 示す。焼なまし状態の炭化物は細かく，しかも均 一に分布しており，これを焼入れると炭化物は完 全に固溶したかにみえる。その後焼もどしを施せ ば, 微細な炭化物が析出してくる。このように MAX 1 の光学顕铔鏡組織は低合金構造用鋼のそ
Table 2. Carbides extracted from steels.

\begin{tabular}{c|c|c|c|c}
\hline \multirow{2}{*}{ Specimen } & \multicolumn{2}{|c|}{$\begin{array}{c}\text { Extracted residue } \\
\text { (wt \%) }\end{array}$} & \multicolumn{2}{c}{ Main carbide } \\
\cline { 2 - 5 } & $(\mathrm{SA})$ & $(\mathrm{H})$ & $(\mathrm{SA})$ & $(\mathrm{H})$ \\
\hline MAX1 & 5.5 & $\begin{array}{c}\left(1025^{\circ} \mathrm{C}\right) \\
1.2\end{array}$ & $\mathrm{M}_{23} \mathrm{C}_{6}$ & $\mathrm{M}_{6} \mathrm{C}$ \\
\hline MAX2 & 11.0 & $\begin{array}{c}\left(1125^{\circ} \mathrm{C}\right) \\
5.0\end{array}$ & $\mathrm{M}_{6} \mathrm{C}$ & $\mathrm{M}_{6} \mathrm{C}$ \\
\hline SKD62 & 7.8 & $\begin{array}{c}\left(1025^{\circ} \mathrm{C}\right) \\
3.5\end{array}$ & $\begin{array}{l}\mathrm{M}_{6} \mathrm{C} \\
\mathrm{M}_{23} \mathrm{C}_{6}\end{array}$ & $\mathrm{M}_{6} \mathrm{C}$ \\
\hline SKD61 & 6.1 & $\begin{array}{c}\left(1025^{\circ} \mathrm{C}\right) \\
2.6\end{array}$ & $\begin{array}{c}\mathrm{M}_{4} \mathrm{C}_{3} \\
\mathrm{M}_{7} \mathrm{C}_{3}\end{array}$ & $\mathrm{M}_{4} \mathrm{C}_{3}$ \\
\hline
\end{tabular}

れに類似している。

しかし，先の焼入れの実験でふれたよらに電子 顕微鏡観察によれば，末固溶炭化物が残っている。 そこで，定電位電解法5゙より炭化物を抽出して， その分析を行った。

Table 2 は烧なましおよび焼入れままの状態で 鋼に含まれる炭化物の分析結果である。まず重量 率をみると, MAX 1 は 4 鋼種の中で炭化物量が もっとも少なく，とくに楛入れのままの状態では $1.2 \%$ の少量となる。

Photo. 2 は焼なまし状態の MAX 1 から抽出 したもののX線回折図形である。この例に示した ように, 残淔には数種類の炭化物が混在している 場合が多い。そこで，熱処理にともなら回折図形 の変化を解析して，主体となっている炭化物を推 定した。これを先の Table 2 に示す。

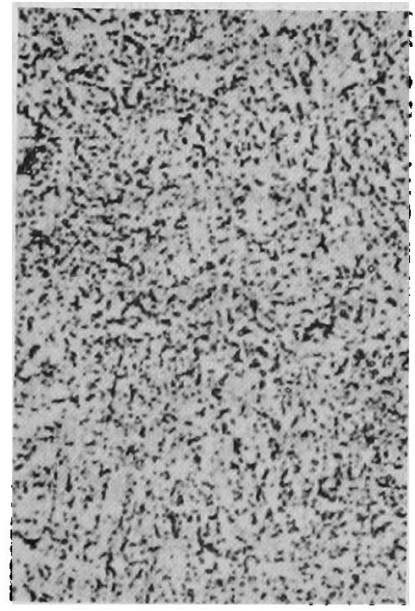

(SA)

$5 \%$ Picral

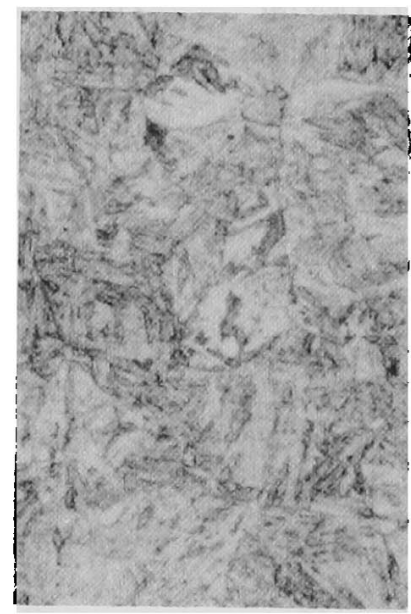

(H) $1025^{\circ} \mathrm{C} \times 20 \mathrm{~min}$ Hot $\mathrm{Q}$ Vilella

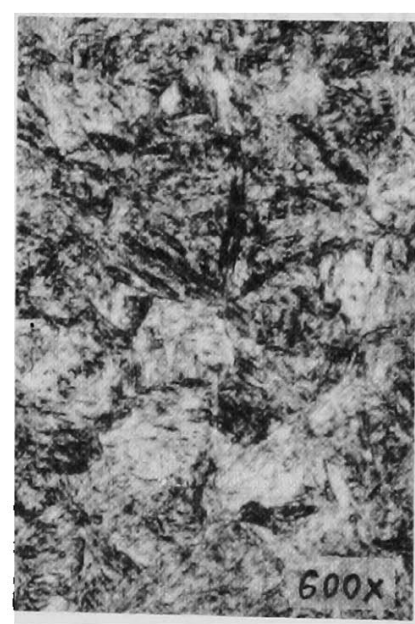

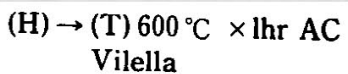

Photo. 1. Microstructures of MAX 1. 


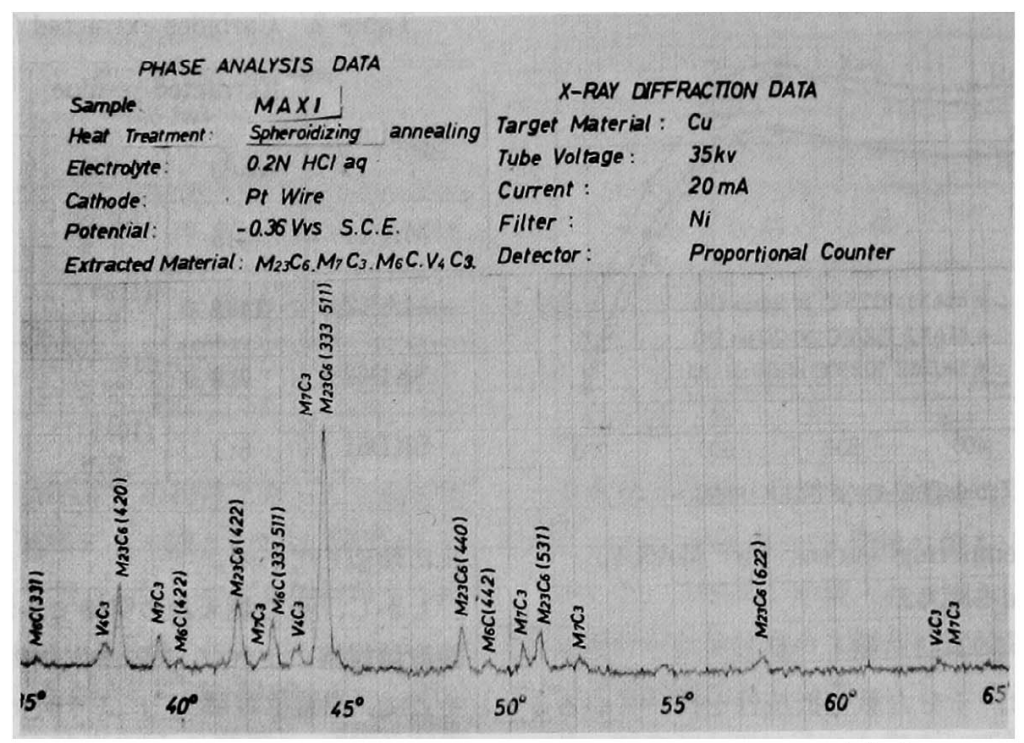

Photo. 2. An Xray diffraction pattern for extraeted materials from MAX 1 annealed.

锛なまし状態の炭化物の種類をみると，Mo お よひW含有量の多いMAX 2 おょび SKD 62 は $\mathrm{M}_{6} \mathrm{C}$ が主体であり ${ }^{6)}$ Ｖ量の高いSKD 61 では M4 $\mathrm{C}_{3}$ が多くなっている。これらの炭化物は固溶 度が小さく，高温から焼入れても未固溶炭化物と して残留しやすい”。

これに対し，MAX 1 の焼もどし状態における 炭化物は $\mathrm{M}_{23} \mathrm{C}_{6}$ が主体であり，この炭化物は低 温の锛入れで完全に固溶する。

なお，4鋼種とも550足以上に狫むどし温度を上 げて行くと，炭化物の重量率が能なまし状態の値 に的和することを認めている。すなわち，二次硬 化により最高かたさに達する焼もどし温度で, 析 出炭化物の量は最大となり，これよりも高温では 炭化物の凝集反応のみが生じていると推察され る。したがって，接なし状態の炭化物量から焼 入れままの状態における値を差引いたるのか，二 次硬化に奇与する析出炭化物の量と考えられる。 このような考え方で Table 2 の重量率をみると， MAX 1 の析出炭化物量は SKD 61 よりる大き く, SKD 62 と同等になっている。一方, MAX 2 の析出炭化物量は $6 \%$ にも達している。MAX 2 の既もどし軟化抵抗性が大きいのは，このためで あろ ${ }^{8)}$ 。

以上の結果を総合すると, MAX 1 の化学組成 では比較的固溶度の大きな炭化物か形成され，低
温の焼入れで未固溶炭化物を極めて少なくするこ とができたものと結論ずけられよら。

また固溶させた炭化物は喯もとしの際に再析出 し，十分な二次硬化を示すといらことになる。

\section{2 MAX 1 の諸特性}

(1) 強度と靶性

末固溶炭化物の減少をねらった目的は, 高強度 に加えて高靱性を具備した鋼を開発することにあ った。そこで, まず MAX 1 の強度と靱性を調查 した。

Fig. 3 は引張試験の結果である。600ㄷ とおける 引張強さは $100 \mathrm{~kg} / \mathrm{mm}^{2}$, 耐力は $75 \mathrm{~kg} / \mathrm{mm}^{2}$ を示 し, 熱間ダイス鋼に要求される強度を満足してい る。

つぎに Fig. 4 で 3 鋼種の衝擊試験結果を比較 した。いずれの温度においても，MAX 1 の衝撃値 は他の 2 鋼種より大きく，高靱性を有しているこ とが確認された。

つぎに強度と勒性の組合わせについて評価し た。Fig. 5 は平滑および切欠引張強さの関係を示 したものである。MAX 1 の大きな特徵は平滑引 張強さを大きくしても, 切欠引張強さが減少しな いといらことである9。これは二次硬化で最高か たさが得られる状態に㜔もどして使用しても，鞄 性の問題がないといらことであり，注目すべき特 質である。また Fig. 6 はかたさと破壊勒性の関係 


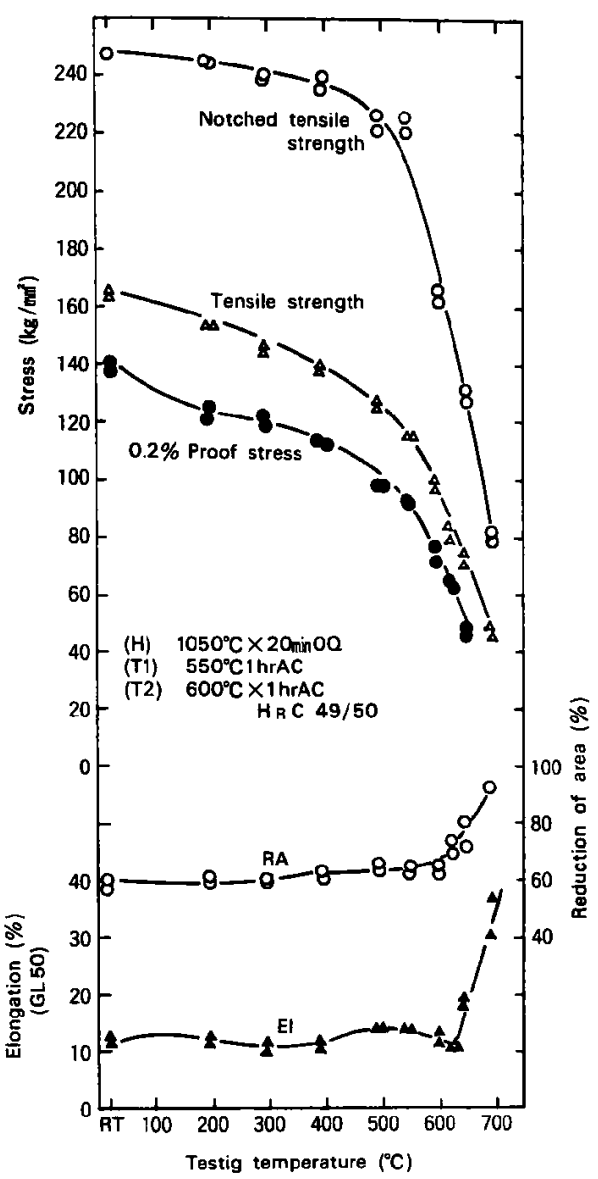

Fig. 3. Tensile properties of MAX 1 .

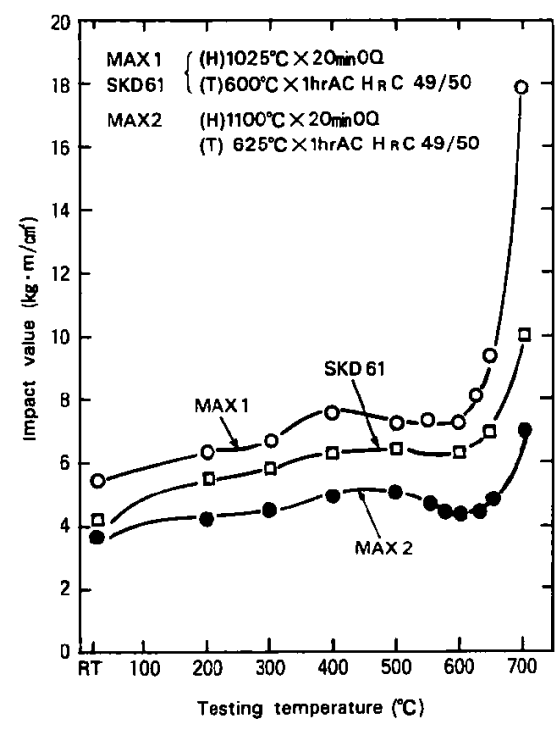

Fig. 4. U-notch charpy impact values of MAX 1, MAX 2 and SKD61.

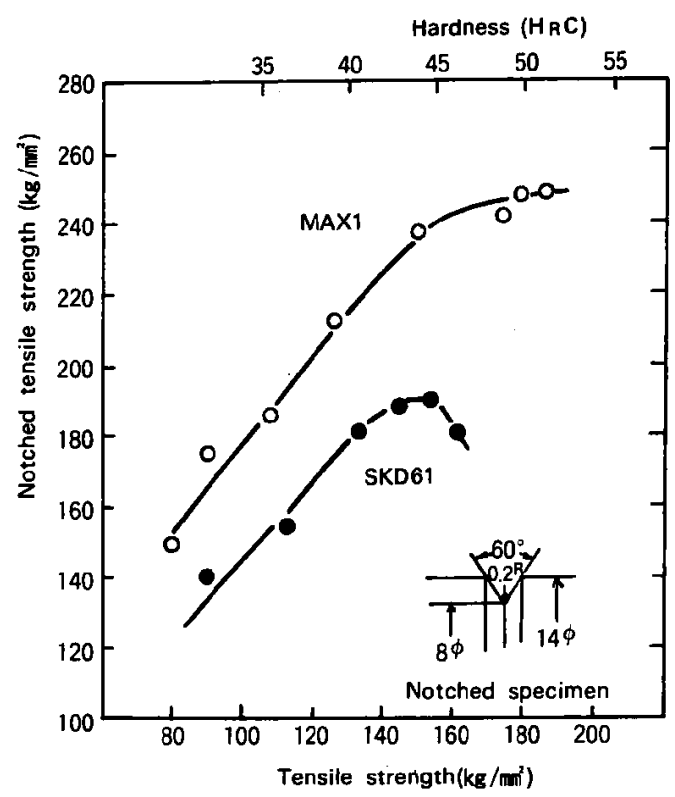

Fig. 5. Relationship between tensile strength and notched tensile strength of MAX 1 and SKD61.

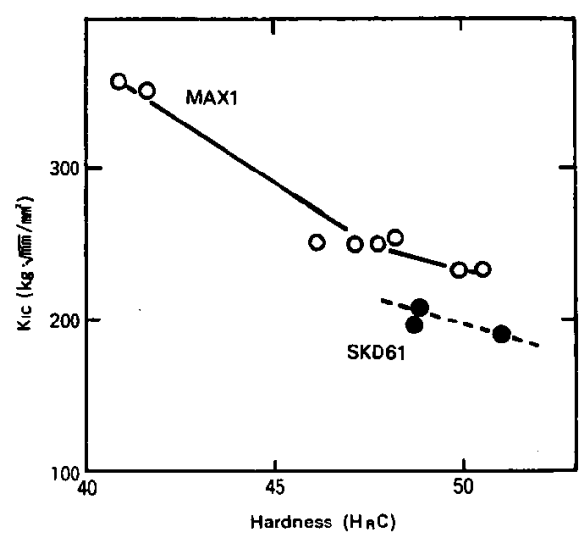

Fig. 6. Fracture toughness of MAX 1 and SKD61.

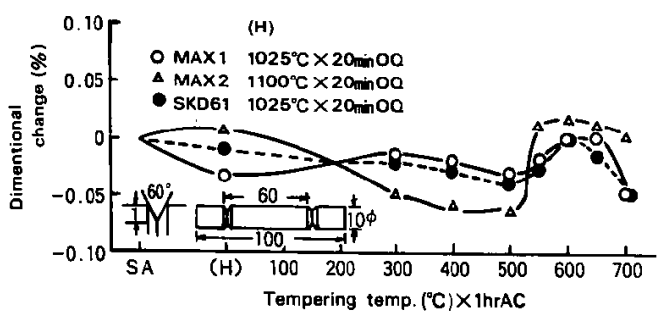

Fig. 7. Dimentional change during heat treatment. 
を示したものである。かたさが大きなところです， MAX 1 の K $\mathrm{IC}$ はSKD 61 の約1.5倍とい5高い 值を示している。

以上の結果から MAX 1 は高強度および高勒性 を兼備した熱間ダイス鋼であるといえよう。

（2）熱処理変寸率

ダイスの寸法精度の点から, 熱処理にともなら 鋼材の寸法変化は重要な特性となる。ここでは小 型試片を用いたが，測定値は実体にも十分適用で きるといわれている ${ }^{10)}$ 。Fig. 7 K 3 鋼種の寸法変 化を示す。実用の锛むどし温度は550～600 $\mathrm{C}$ と考 えられるか，この温度範囲における变寸率は極め て小さい。

（3）高温疲労強さ

ダイスは高温に打けるくり返した応力を受ける ので，熱間ダイス鋼には高温疲労強さが要求され る。Fig. 8 に小野式回転曲げ試験機によって測定 したS-N曲線を示す。MAX1の調質かたさは SKD 62 より低いにもかかわらず，高応力側の破 断寿命性 MAX 1 の方が吱めて大きくなってい る。これは MAX 1 の焼もどし抵抗性が大きいと いらことたけの効果によるものとは考えられな いむしろ未固溶炭化物の含有量が少なく，勤性 が高いためであろら

(4) 耐ヒート・チェック性

実際に使用される条件では，ダイスが急激な温

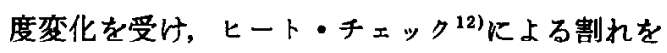
生ずるために廃却される場合が多いので, MAX 1 の耐ヒート・チェック性を調査した。Fig.9 Kそ の試験結果を示す。試験方法は傘型の試片にガス ・バーナー加熱一水冷の熱サイクルを付与し，く

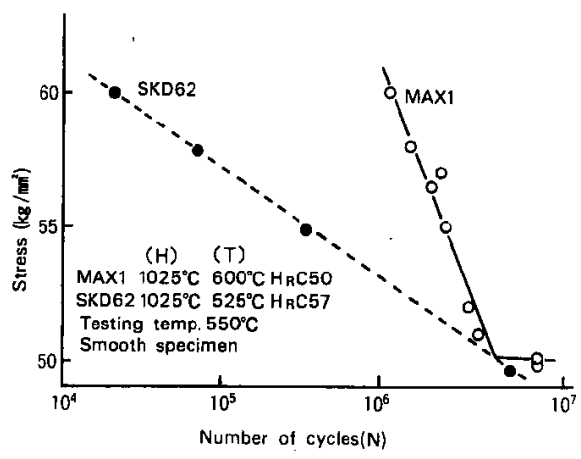

Fig. 8. Rotating bending fatigue lifes of MAX 1 and SKD62 at $550^{\circ} \mathrm{C}$.
り返し数（N）が規定値となったところで, 円板 外周のクラックを観察するとい5すのである。4 鋼種とも $\mathrm{N}=500$ ～1000でクラック発生頻度の最 大值を示している。これはクラックの平均長さの 変化にみられるよらに，それ以上の熱サイクルを 受けると，多数の小さなクラックが少数の大きな クラックに統合されるためである。

$\mathrm{N}=2000$ でクラック数がもっとる小さいのは MAX 2 であるが,梁さか大きくなっており，数お よひ深さの両面から評価した場合は, MAX 1 の 耐ヒート・チェック性がもっともすぐれている。

なお, MAX 1 のクラック伀播に異方性が少な いこともその特質として上げられてよい。

(5) 耐摩耗性

くり返し応力扣よびヒート・チェックによるク ラックの発生がなくとも，面の摩耗量が大きくな れば，ダイスは廃却されることになるので，つぎ にMAX 1 の耐摩耗性を調查した。ただし，実際 の使用条件を再現することは困難なので，通常の 大越式摩耗試験機を用いた。相手材には軟質の

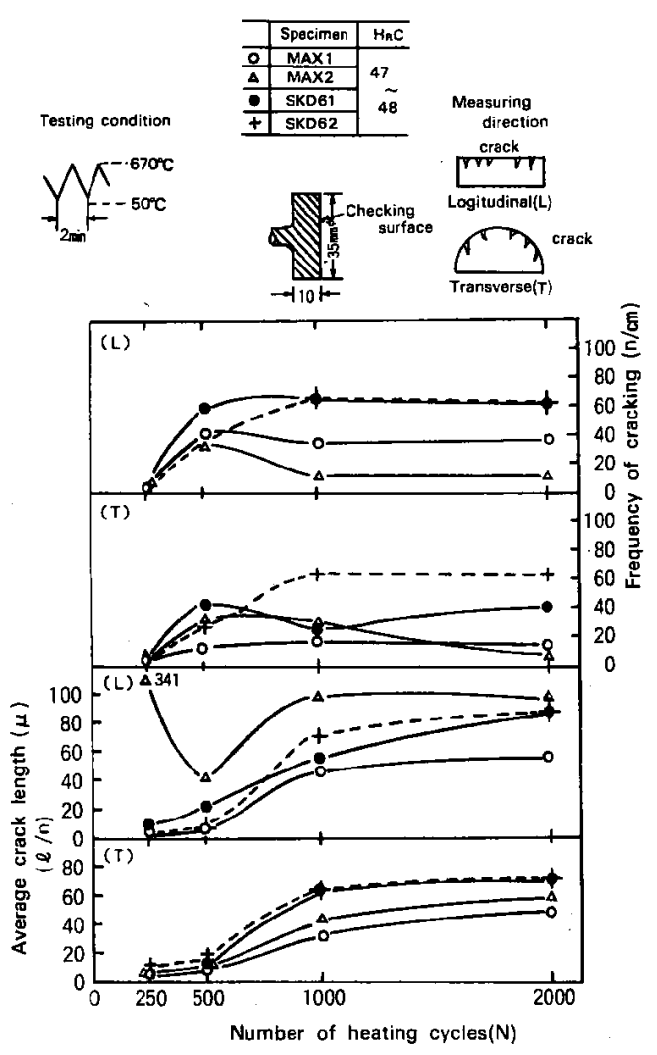

Fig. 9. Results of heat-checking test. 


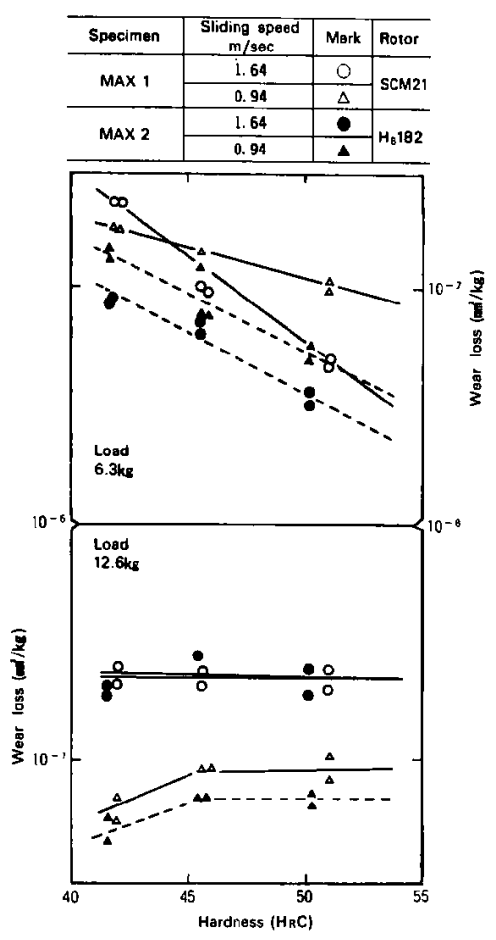

Fig. 10. Wear test results of MAX 1 and MAX 2 .

SCM 21 を選定した。Fig.10 はかたさと比摩耗量 の関係である。小荷重の場合には焼もどし，かた さを高目にとれば耐摩耗性が向上するが，高荷重 の場合にはかたさを上げても効果がない。同一か たさの MAX 2 は高荷重でも比摩耗量が少ない が、これは末固溶炭化物が耐摩耗性に寄与してい るためであろら。

MAX 1 の耐摩耗性は MAX 2 より劣っている が，他の鋼種と此較すれば同等である。さらに大 きな耐摩耗性が要求される場合には，窒化等の表 面処理を適用すればよい。

（6）耐Al溶損性

上でのべた機械的損耗のほかにダイキャスト では溶融金属による腐食が問題となるので,ここ ではMAX 1 のAl溶損を調査した。Fig. 11 に浸漬 後の直径减少率を示した。MAX 1 は現用鋼と同 等の耐食性を示しており，Al ダイキャスト型とし て使用可能と考学られる。

(7) 窒 化 性

ダイス鋼そのものの材質改善とは別に，ダイス の特珄を向上させる有効な手段として表面処理が

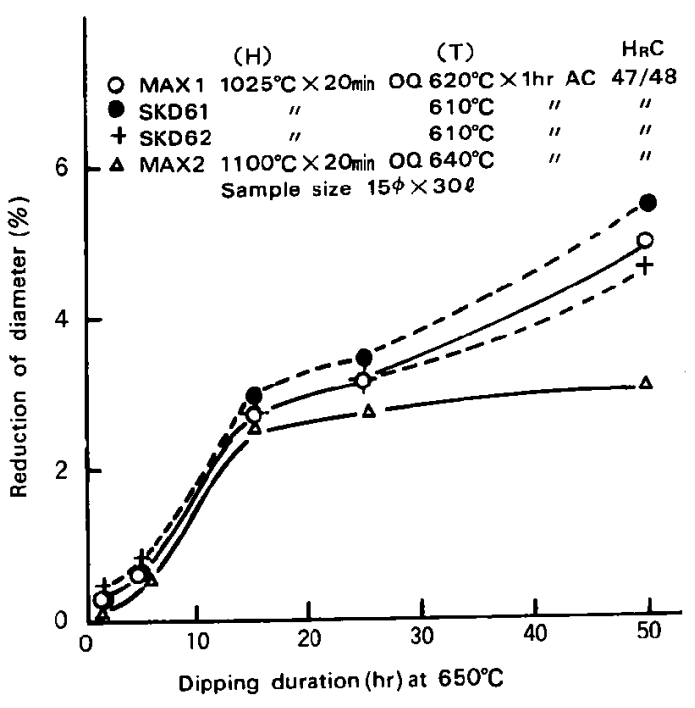

Fig. 11. Errosion in molten aluminum alloy (ADC 1)

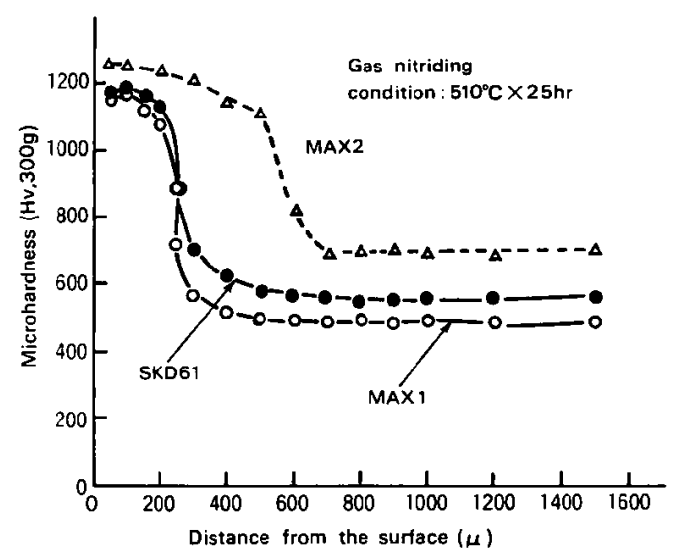

Fig. 12. Hardness distribution of MAX 1, MAX 2 and SKD61 nitrided at the indica. ted condition.

あり，適用の例も多いのでここではガス窒化を とり上げて試験してみた。Fig. 12 は処理後の断面 かたさ分布である。MAX 1 は熱間ダイスとして 必要な深さまで容易に窒化され，窒化層も強固な むのが得られるので，ガス窒化の啇用による特性 向上が期待できる。
4.
と
め

MAX 1 の特性として以下を確認した。

（1）焼入れ時の末固容炭化物量が極めて少な 
く、しかむ十分な二次硬化が得られる。

（2）現用鋼と同じ温度から褡入れることができ る。

（3）熱処理变寸率が非常に小さい。

(4) 高温疲労強さが大きい。

(5) ヒート・チェックによる割れが浅い。

(6) 耐摩耗性がよい。

(7) Al溶損による减耗が少ない。

（8）ガス窒化が適用できる。

（文献）

1) Alan M. Bayer : Metal Progr., 97 (1970) 4,86

2）佐藤,相沢 : プレス型材料と熱処理，(昭47）, 3 日刊工業新聞社
3）水野：特殊鋼，20（1971）9，34

4）佐久間, 西沢 : 日本金属学会会報, 10 (1971) 5,279

$5 ）$ 増本: 鉄と鋼, 55 (1969), 1347

6) H. J. Golceschmidt : JISI., 160 (1948), 345

7) 仁平：都立工業技術センター研究報告, (昭 48) 3,53

8 ) Mott, N.F. and Nabarro, F. R. N. : Rept. Conf. Strength of Solids, P. 1. Physical Society, (1948)

9）上原：シンボジゥム, “工具鋼に関する最近 の進歩"（日本金属学会, 1974), 1

10）伊藤，磯部，加藤：電気製鋼，45 (1974)，13

11）荒木：鉄鋼材料学, (昭45)，148 丸善

12）藤原：大阪大学博士論文 (1962)，17

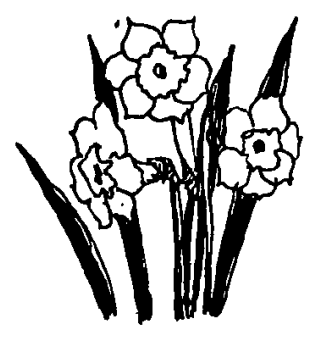

